\title{
Performance characteristics and blood profile of broiler chickens fed corn-cobs based diets with or without enzyme supplementation
}

Lawrence-Azua, O. O., Saka, A. A., Yahaya, M. O., Ijadunola, T. I., Bernard, A. M. and

Ogunfolabo, L. A.

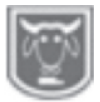

$$
\begin{gathered}
\text { Federal College of Animal Health and Production Technology, } \\
\text { P.M.B. 5029, Moor Plantation, Ibadan. }
\end{gathered}
$$

Abstract

Email: saka.azeez@gmail.com

Corn-Cob Meal (CCM) is a waste product derived from maize grain shelling corn cob which constitutes nuisance to the environment and it can be included in poultry diet in order to reduce competition between man and animal. Hence, a 63-day feeding trial was conducted in a completely randomized design to determine performance characteristics and blood profile of broiler chickens fed corn-cobs based diets with or without enzyme supplementation. One hundred and sixty five (165) birds were randomly allotted into five dietary treatment groups; $T_{1}$ : (0\% CCM), $T_{2}$ (10\% CCM without enzyme), $T_{3}$ (20\% CCM without enzyme), $T_{4}(10 \%$ CCM with enzyme), $T_{5}(20 \%$ CCM with enzyme) with each treatment comprising three replicates of eleven birds per replicate. Parameters measured include performance characteristics, haematological and serum biochemical indices. The result revealed that there were no significant difference $(P>0.05)$ on performance characteristics of broiler chicken observed except for Average Daily Feed Intake (ADFI) and the Feed Conversion Ratio (FCR). Birds fed 10\% and 20\% CCM based diet without enzyme recorded the highest value of ADFI (129.38 g/b/d and $130.85 \mathrm{~g} / \mathrm{b} / \mathrm{d})$ while birds fed $20 \%$ CCM based diet with enzyme supplementation had the best FCR value (2.18). The haematological parameters were not significantly influenced $(P>0.05)$ by the diets except for lymphocytes and heterophil count with the highest lymphocytes value in $T_{2}(68.00 \%)$ and the lowest value in $T_{5}(53.67 \%)$. Birds on $T_{5}$ had significantly $(P<0.05)$ highest heterophil value $(40.67 \%)$. The serum biochemical indices were not significantly influenced $(P>0.05)$ by the diets except for aspartate aminotransferase. However, values obtained in this study fell within the normal range recommended for healthy broiler chicken. Based on this result, it can be concluded that CCM with enzyme supplementation can be incorporated into broiler diet up to $20 \%$ without any detrimental effect on their performance and blood profile.

Keywords: Broiler, Corn-Cob Meal, Performance, Enzymes, Blood profile.

\section{Introduction}

The high cost of feed ingredients which accounts for $60-80 \%$ of the total cost of production clearly indicates that the production of cereal grains for livestock business is grossly inadequate (Tewe et al., 1976). More so, energy sources are the most important and expensive feedstuffs especially maize which accounts for the largest proportion of about $50-55 \%$ of the poultry diet (Afolayan et al., 2002). This invariably has led to stiff competition between humans and animals over the limited supply of grains therefore affecting the poultry industry in Nigeria (Ahaotu et al., 2009). Thus, there is an urgent need to divert attention toward exploitation of other tropical sources. One of such potential source that has not been fully utilized is corn-cobs which are generally not used for human consumption. Corn-cob is a waste product and readily available in Nigeria which is an underutilized by product from the processing of harvested maize. The 
amount of maize cob generated annually in the country increases as more people venture into the cultivation of maize, but they have low feeding value because of its poor protein content, energy, minerals and vitamins (Akinfemi et al., 2009). The militating problem affecting the utilization of corn cobs in chicken diet is due to high fibre content. The roles of enzymes as additive in poultry diets is well established (Atteh, 2000; Abdulrashid et al., 2007). The authors observed that enzyme addition to monogastric feed reduced viscosity of the digesta in the intestine as opposed to a situation of association with digestion of cereal grain (by-products) and showed a marked improvement on the various morphological effects of feeding fibrous materials to non- ruminant. The determination of blood component values using laboratory is an important procedure to aid the diagnosis of several diseases and dysfunctions, as they provide reliable results, and may also give inputs for research studies on nutrition, physiology, and pathology (Bounous et al., 2000). Therefore, the objectives of this study were to evaluate the performance and blood profile of broiler chickens fed corn-cobs based diets with or without enzyme supplementation.

\section{Materials and methods Experimental site}

The experiment was conducted at the Teaching and Research Farm of the Federal College of Animal Health and Production Technology, Moor Plantation, Ibadan. The area lies within the rain forest ecological zone, and falls within longitude and latitude $7^{0} 27^{1}$ and $3^{0} 25^{1}$ respectively at altitude 200 $300 \mathrm{~m}$ above the sea level with an annual rainfall of about $1250 \mathrm{~mm}$. The temperature and relative humidity ranges from $30-35^{\circ} \mathrm{C}$ and $76-84 \%$ respectively.

\section{Experimental animals, management and design}

A total of 165 -1- day old Cobb 500 chicks were purchased from a reputable hatchery in Ibadan and used for this experiment. They were brooded for two (2) weeks under similar managerial and hygienic conditions. All vaccination schedules and medication were followed accordingly. Birds were supplied with feed and water ad libitum. After one week of adaptation period, the birds were randomly allotted to five dietary treatments in a completely randomized design and the experiment lasted for nine weeks.

\section{Preparation of experimental diet}

The corn cob was obtained from Omi- Adio market, Ido local government area of Ibadan, Oyo state. The cobs was sun-dried for two days and subsequently milled to form the corn cob meal (CCM) that were later incorporated into the experimental diets as follows; $\mathrm{T}_{1}$ : control $\operatorname{diet}(0 \% \mathrm{CCM})$, $\mathrm{T}_{2}$ (10\% CCM without enzyme), $\mathrm{T}_{3}(20 \%$ CCM without enzyme), $\mathrm{T}_{4}(10 \% \mathrm{CCM}$ with enzyme), $\mathrm{T}_{5}(20 \%$ CCM with enzyme)

\section{Data collection}

\section{Feed intake and live weight changes}

The growth of the birds in response to the experimental diets was monitored by taking their pre-experimental body weights, followed by weighing on a weekly basis prior to feeding. Feed offered daily per bird was recorded and refusal was weighed and recorded to compute feed intake on daily basis.

\section{Collection of blood samples}

At the end of the experiment, blood samples of approximately $6 \mathrm{ml}$ were collected from nine (9) randomly selected experimental birds per treatment via the jugular vein using hypodermic needle and syringe. About $3 \mathrm{ml}$ of blood sample collected was released into the sample bottles containing Ethyl Diamine Tetra Acetic Acid (EDTA) as 
Lawrence-Azua, Saka, Yahaya, Ijadunola, Bernard and Ogunfolabo

Table 1: Gross composition and proximate analysis of the experimental diets at starter phase.

\begin{tabular}{|c|c|c|c|c|c|}
\hline Ingredient (\%) & $\mathrm{T}_{1}(\mathbf{0 \%} \mathbf{C C})$ & $\mathrm{T}_{2}\left(\mathbf{1 0 \%} \mathrm{CC}^{-}\right)$ & $\mathrm{T}_{3}\left(\mathbf{2 0} \% \mathbf{C C}^{-}\right)$ & $\mathrm{T}_{4}\left(\mathbf{1 0} \% \mathbf{C C}^{+}\right)$ & $\mathrm{T}_{5}\left(\mathbf{2 0} \% \mathbf{C C}^{+}\right)$ \\
\hline Maize & 60.00 & 52.23 & 44.50 & 52.23 & 44.50 \\
\hline Corn cobs & - & 6.00 & 12.00 & 6.00 & 12.00 \\
\hline Soybean & 30.00 & 31.70 & 33.50 & 31.70 & 33.50 \\
\hline GNC & 7.30 & 8.40 & 8.20 & 8.40 & 8.20 \\
\hline Enzyme & - & - & - & 0.50 & 0.50 \\
\hline *other & 1.85 & 1.85 & 1.85 & 1.85 & 1.85 \\
\hline Total & 100.00 & 100.00 & 100.00 & 100.00 & 100.00 \\
\hline \multicolumn{6}{|l|}{ Determined Analysis } \\
\hline Dry matter & 90.08 & 90.48 & 90.25 & 90.56 & 90.11 \\
\hline Crude protein & 21.49 & 22.89 & 23.00 & 22.70 & 21.57 \\
\hline Crude fibre & 4.54 & 4.03 & 4.06 & 3.98 & 3.89 \\
\hline Ether extract & 3.56 & 3.76 & 3.87 & 3.84 & 3.64 \\
\hline Ash & 5.65 & 5.69 & 5.84 & 6.11 & 5.72 \\
\hline Nitrogen free extract & 57.07 & 57.01 & 57.51 & 57.79 & 57.16 \\
\hline
\end{tabular}

Table 2: Gross composition and Proximate Analysis of the experimental diets at finisher Phase Level

\begin{tabular}{|c|c|c|c|c|c|}
\hline Ingredient (\%) & $\mathrm{T}_{1}(\mathbf{0} \% \mathbf{C C})$ & $\mathrm{T}_{2}\left(\mathbf{1 0} \% \mathbf{C C}^{-}\right)$ & $\mathrm{T}_{3}\left(\mathbf{2 0} \% \mathbf{C C}^{-}\right)$ & $\mathrm{T}_{4}\left(\mathbf{1 0} \% \mathbf{C C}^{+}\right)$ & $\mathrm{T}_{5}\left(\mathbf{2 0} \% \mathbf{C C}^{+}\right)$ \\
\hline Maize & 65.00 & 56.00 & 48.15 & 56.00 & 48.15 \\
\hline Corn cobs & - & 6.00 & 12.00 & 6.00 & 12.00 \\
\hline Soybean & 24.65 & 27.40 & 29.80 & 27.40 & 29.80 \\
\hline Enzyme & - & - & - & 0.50 & 0.50 \\
\hline *other & 9.96 & 9.96 & 9.96 & 9.96 & 9.96 \\
\hline Total & 100.00 & 100.00 & 100.00 & 100.00 & 100.00 \\
\hline \multicolumn{6}{|l|}{ Determined Analysis } \\
\hline Dry matter & 90.62 & 90.33 & 90.60 & 90.15 & 90.23 \\
\hline Crude protein & 19.72 & 22.89 & 19.68 & 19.52 & 19.69 \\
\hline Crude fibre & 4.76 & 3.89 & 3.86 & 3.78 & 3.75 \\
\hline Ether extract & 3.76 & 3.66 & 3.71 & 3.59 & 3.61 \\
\hline Ash & 5.42 & 5.79 & 5.84 & 5.87 & 6.09 \\
\hline Nitrogen free extract & 56.05 & 56.99 & 47.89 & 56.99 & 47.87 \\
\hline
\end{tabular}

$\mathbf{0 . 0 5 \%}$ vegetable oil; $4.3 \%$ Wheat offal; $4.00 \%$ groundnut cake: $1.00 \%$ Diacalcium phosphate; $0.25 \%$ Premix; $0.10 \%$ Methionine; $0.01 \%$ Lysine; $0.25 \%$ Salt. CC : Corn cob without enzyme, $\mathrm{CC}^{+}$: Corn cob with enzyme. ME: Metablizable Energy; Vit. A: 10,000 iu; Vit. D 2 : 2000 iu; Vit. E: 23 mg; Vit. K: $2 \mathrm{mg}$; Vit $B_{1}: 1.8 \mathrm{mg}$; Vit. $B_{2}: 5.5 \mathrm{mg}$; Niacin: $27.5 \mathrm{mg}$; Pantothenic acid: $7.5 \mathrm{mg}$; Vit $B_{12}: 0.015$ mg; Folic acid: $0.75 \mathrm{mg}$; Biotin: $0.06 \mathrm{mg}$; Choline chloride: $300 \mathrm{mg}$; Cobalt: $0.2 \mathrm{mg}$; Copper: $3 \mathrm{mg}$; Iodine: $1 \mathrm{mg}$; Iron: $20 \mathrm{mg}$; Manganese: $40 \mathrm{mg}$; Selenium: $0.2 \mathrm{mg}$; Zin: $30 \mathrm{mg}$; Antioxidant: $1.25 \mathrm{mg}$

anticoagulant and the bottles were gently shaken to ensure proper mixing of the blood with EDTA to prevent coagulation and the remaining $3 \mathrm{ml}$ was poured into a plain sample bottle. Blood samples were analyzed according to routinely available clinical methods. The following parameters Packed cell volume (PCV), Haemoglobin $(\mathrm{Hb})$, Red blood cell (RBC), white blood cell (WBC), Mean corpuscular volume (MCV), Mean corpuscular haemoglobin concentration (MCHC), Mean corpuscular haemoglobin $(\mathrm{MCH})$, Differential WBC namely; Monocytes, Neutrophils, Lymphocytes and heterophil. The PCV was determined using the wintrobe haematocrit method described by (Wintrobe, 1933). $\mathrm{WBC}$ and $\mathrm{RBC}$ were determined using haemocytometer after appropriate dilution (Dacie and Lewis, 1984), Haemoglobin and Mean corpuscular volume (Brown, 1976). Biochemical components of the serum samples estimated were total protein $(\mathrm{g} / \mathrm{dl})$ was determined according to Biuret 


\section{Broiler chickens fed corn-cobs based diets with or without enzyme supplementation}

Method (Reinhold, 1953) while albumin (g/dl) level was obtained using Bromocresol green method as described by (Peter et al., 1982). Blood glucose (mg/dl) level was determined according to the method recommended by (Cooper and Daniel, 1970), urea (mg/dl), aspartate aminotransferase (AST) and alanine aminotransferase (ALT) were determined using spectophotometric methods. MCV, $\mathrm{MCH}$ and $\mathrm{MCHC}$ were deduced according to Jain (1986) as follows: MCV (fl) =
$\mathrm{PCVX} 10 / \mathrm{RBCX} 10 ; \mathrm{MCH}(\mathrm{pg})=$ $\mathrm{HbX} 10 / \mathrm{RBC}(10) ; \mathrm{MCHC}(\%)=$ $\mathrm{HbX100/PCV}$

\section{Chemical analysis}

An aliquot of daily feed samples (concentrates) was collected, oven-dried, ground and sieved through a $2-\mathrm{mm}$ sieve and stored in airtight container for proximate (AOAC, 2000). Nitrogen Free Extract (NFE) was determined by subtracting sum of $(\%$ Moisture $+\%$ Crude Protein $+\%$ Ether extract $+\%$ Crude fibre + $\%$ Ash) from 100.

Table 3: Performance characteristic of broiler chicken fed Corn-Cobs based diet with or without enzyme supplementation

\begin{tabular}{lllllll}
\hline Parameters & $\mathrm{T}_{1}(0 \% \mathrm{CC})$ & $\mathrm{T}_{2}\left(10 \% \mathrm{CC}^{-}\right)$ & $\mathrm{T}_{3}\left(20 \% \mathrm{CC}^{-}\right)$ & $\mathrm{T}_{4}\left(10 \% \mathrm{CC}^{+}\right)$ & $\mathrm{T}_{5}\left(20 \% \mathrm{CC}^{+}\right)$ & $\mathrm{SEM}$ \\
\hline Initial Wt $(\mathrm{g} / \mathrm{b})$ & 110.51 & 111.58 & 113.06 & 117.48 & 119.15 & 1.44 \\
Final body wt $(\mathrm{g} / \mathrm{b})$ & 2941.30 & 3011.30 & 2782.10 & 3116.60 & 2977.80 & 57.62 \\
Total Wt gain $(\mathrm{g} / \mathrm{b})$ & 2830.80 & 2899.70 & 2669.10 & 2999.10 & 2858.60 & 57.34 \\
ADWtgain $(\mathrm{g} / \mathrm{b} / \mathrm{d})$ & 50.55 & 51.78 & 47.66 & 53.56 & 51.05 & 1.02 \\
Total fd intake $(\mathrm{g} / \mathrm{b})$ & $6443.70^{\mathrm{b}}$ & $7245.20^{\mathrm{a}}$ & $7327.30^{\mathrm{a}}$ & $6886.90^{\mathrm{ab}}$ & $6217.30^{\mathrm{b}}$ & 141.06 \\
ADFI $(\mathrm{g} / \mathrm{b} / \mathrm{d})$ & $115.07^{\mathrm{b}}$ & $129.38^{\mathrm{a}}$ & $130.85^{\mathrm{a}}$ & $122.98^{\mathrm{ab}}$ & $111.02^{\mathrm{b}}$ & 2.52 \\
FCR & $2.29^{\mathrm{b}}$ & $2.50^{\mathrm{ab}}$ & $2.75^{\mathrm{a}}$ & $2.32^{\mathrm{b}}$ & $2.18^{\mathrm{b}}$ & 0.07 \\
\hline
\end{tabular}

${ }_{\text {a,b,ab }}$ Means in the same row with different superscripts are significantly different $(\mathrm{P}<0.05)$.

Wt: Weight, ADWt: Average daily weight gain, fd: Feed, ADFI: Average daily feed intake, FCR: Feed Conversion ratio, $\mathrm{CC}^{-}$: Corn cob without enzyme, $\mathrm{CC}^{+}$: Corn cob with enzyme.

Haematological indices of Broiler Chicken fed corn-cobs based diet with or without enzyme supplementation is presented in Table 4. There were no significant difference $(\mathrm{P}>0.05)$ on the haematological indices of broiler chicken investigated except the lymphocytes and heterophil which were significantly influenced by the dietary treatment. Lymphocytes use the blood to travel round the body but can wander freely in other types of tissues using the lymphatic channels. An increase in lymphocytes number is in response to viral, parasitic and bacterial infection of the animal's body (Coles, 1986). However, lymphocytes and heterophil values obtained in this study fell within the normal range of values recommended for healthy birds (Mitruka and Rawnsley, 1977). This suggest that CCM based diet may not have had any negative effect on haematology of birds.

Indicated in Table 5 are the Serum biochemical indices of broiler chicken fed Corn-Cobs based diet with or without enzyme supplementation. Apart from aspartate aminotransferase (AST) that was significantly $(\mathrm{P}<0.05)$ influenced by the dietary treatments, all other serum biochemical indices measured were not significantly $(\mathrm{P}>0.05)$ influenced across the dietary treatments. AST varied significantly $(\mathrm{P}<0.05)$ across the dietary treatment with birds fed 10\% CCM based diet without enzyme supplementation recorded the highest value (234.40 iu/l) followed by those fed 20\% CCM without enzyme supplementation (169.62 iu/l) and $10 \% \mathrm{CMM}$ with enzyme supplementation (170.50 iu/l) that were statistically similar 
$(\mathrm{P}>0.05)$ but they were significantly higher $(\mathrm{P}<0.05)$ than those on $0 \%$ CCM $(216.22$ $\mathrm{iu} / 1)$ and $20 \%$ CCM with enzyme supplementation $(196.16 \mathrm{iu} / \mathrm{l})$ that were also statistically similar $(\mathrm{P}>0.05)$. Aspartate aminotransferase (AST) differed significantly $(\mathrm{P}<0.05)$ as the inclusion level of corn-cobs with or without enzyme supplementation varies in feed. Enzymes are protein catalysts present mostly in living cells and are constantly and rapidly degraded although, renewed by new synthesis (Coles, 1986). According to (Zilva and Pannall, 1984), normal enzyme level in serum is a reflection of a balance between synthesis and their release, as a result of the different physiological processes in the body. Transaminase enzymes are those mostly responsible for the synthesis of non-essential amino acids through the process known as transamination (Carola et al., 1990). In this study, the relatively close but low mean levels observed for the transaminases could be an indication that the test diets did not differ in their effects on enzyme secretion mechanism. According to Keele and Neil (1971) serum levels of AST are significantly high under disease and morbid conditions involving injuries to large numbers of metabolically active cells. However, the result of this study suggests a contrary situation thus indicating the potential of the enzymes supplementation on the fibrous diet fed to the chicken.

Table 4: Haematological indices of broiler chicken

fed Corn-Cobs based diet with or without enzyme supplementation

\begin{tabular}{|c|c|c|c|c|c|c|}
\hline Parameters & $\mathrm{T}_{1}(0 \% \mathrm{CC})$ & $\mathrm{T}_{2}\left(10 \% \mathrm{CC}^{-}\right)$ & $\mathrm{T}_{3}\left(20 \% \mathrm{CC}^{-}\right)$ & $\mathrm{T}_{4}\left(10 \% \mathrm{CC}^{+}\right)$ & $\mathrm{T}_{5}\left(20 \% \mathrm{CC}^{+}\right)$ & $\mathrm{SEM} \pm$ \\
\hline PCV (\%) & 25.00 & 28.67 & 25.00 & 25.33 & 23.67 & 0.83 \\
\hline $\mathrm{Hb}(\mathrm{g} / \mathrm{dl})$ & 8.30 & 9.53 & 8.33 & 8.43 & 7.90 & 0.27 \\
\hline $\operatorname{RBC}\left(10^{12} / \mathrm{L}\right)$ & 3.63 & 3.66 & 3.43 & 3.91 & 3.58 & 0.12 \\
\hline $\mathrm{WBC}\left(10^{3} / \mathrm{L}\right)$ & 16.03 & 16.52 & 17.30 & 18.20 & 17.23 & 0.31 \\
\hline Lymphocyte $(\%)$ & $57.00^{\mathrm{ab}}$ & $68.00^{\mathrm{a}}$ & $63.00^{\mathrm{ab}}$ & $65.33^{\mathrm{ab}}$ & $53.67^{\mathrm{b}}$ & 2.08 \\
\hline Heterophil (\%) & $39.33^{\mathrm{ab}}$ & $28.00^{\mathrm{b}}$ & $31.33^{\mathrm{ab}}$ & $29.00^{\mathrm{ab}}$ & $40.67^{\mathrm{a}}$ & 1.15 \\
\hline Monocytes (\%) & 2.00 & 2.00 & 2.67 & 3.67 & 2.67 & 0.31 \\
\hline Eosinophil (\%) & 1.33 & 3.00 & 2.67 & 1.67 & 3.33 & 0.39 \\
\hline Basophil (\%) & 0.33 & 0.33 & 0.33 & 0.33 & 0.00 & 0.12 \\
\hline $\operatorname{MCV}(p g)$ & 69.08 & 80.88 & 72.54 & 66.34 & 67.37 & 3.42 \\
\hline $\mathrm{MCH}(\mathrm{fl})$ & 22.91 & 26.90 & 24.19 & 22.08 & 22.49 & 1.14 \\
\hline $\mathrm{MCHC}(\mathrm{g} / \mathrm{dl})$ & 33.19 & 33.25 & 33.35 & 33.35 & 33.28 & 0.03 \\
\hline
\end{tabular}

Table 5: Serum biochemical indices of broiler c hicken fed Corn-Cobs based di et with or witho ut enzyme supplementation

\begin{tabular}{lllllll}
\hline Parameters & $\mathrm{T}_{1}(0 \% \mathrm{CC})$ & $\mathrm{T}_{2}\left(10 \% \mathrm{CC}^{-}\right)$ & $\mathrm{T}_{3}\left(20 \% \mathrm{CC}^{-}\right)$ & $\mathrm{T}_{4}\left(10 \% \mathrm{CC}^{+}\right)$ & $\mathrm{T}_{5}\left(20 \% \mathrm{CC}^{+}\right)$ & $\mathrm{SEM} \pm$ \\
\hline Total Protein $(\mathrm{g} / \mathrm{dl})$ & 4.00 & 3.97 & 3.93 & 3.03 & 4.08 & 0.20 \\
Albumin $(\mathrm{g} / \mathrm{dl})$ & 1.80 & 2.02 & 2.01 & 1.83 & 1.94 & 0.05 \\
Globulin $(\mathrm{g} / \mathrm{dl})$ & 2.20 & 1.95 & 1.93 & 1.20 & 2.14 & 0.18 \\
Glucose $(\mathrm{mg} / \mathrm{dl})$ & 171.48 & 163.89 & 175.18 & 187.96 & 154.63 & 5.60 \\
Urea $(\mathrm{mg} / \mathrm{dl})$ & 4.45 & 4.39 & 3.76 & 4.69 & 3.70 & 0.21 \\
Creatinine $(\mathrm{mg} / \mathrm{dl})$ & 0.30 & 0.28 & 0.39 & 0.60 & 0.52 & 0.05 \\
AST $(\mathrm{iu} / \mathrm{l})$ & $216.22^{\mathrm{ab}}$ & $234.40^{\mathrm{a}}$ & $169.62^{\mathrm{b}}$ & $170.50^{\mathrm{b}}$ & $196.16^{\mathrm{ab}}$ & 9.58 \\
ALT $(\mathrm{iu} / \mathrm{l})$ & 6.45 & 5.28 & 4.64 & 7.16 & 4.69 & 0.43 \\
\hline
\end{tabular}

$\overline{a, b, a b}$ Means in the same row with different superscripts are significantly different $(\mathrm{P}<0.05)$.

$\mathrm{CC}^{-}$: Corn cob without enzyme, $\mathrm{CC}^{+}$: Corn cob with enzyme. AST: Aspartate aminotransferase, ALT: Alanine aminotransferase 


\section{Conclusion}

The utilization of the crop residues; CCM based diet with enzyme supplementation up to $20 \%$ has no deleterious effects on the nutritional and health conditions as determined by the blood analysis of broiler chicken. Results of the haematological indices showed that lymphocyte and heterophil values were significantly different $(\mathrm{P}<0.05)$ among the treatment groups. Serum biochemistry showed that AST values was influenced $(\mathrm{P}<0.05)$ by the dietary. The other values of the blood biochemical indices and the parameters of hematology were similar ( $p>0.05)$ among dietary groups.

\section{References}

Abdulrashid, M., Agwuobi, L. N., Jokthan, G. E. and Abdul., S. B. 2007 . Carcass quality characteristics of broiler finisher fed taro (Colocasia esculanta) cocoyam meal In : Book of abstract of the 32nd annual conference, NSAP, held at the university of Calabar, Calabar, Nigeria. 32: 457 -460 .

Afolayan, G. G., Olorode, B. R., Uko, J. O., Junaidu, A. U. and Fanimo, A. O. 2002. The replacement value of maize bran for maize in broiler finisher diets. Proceedings of 27 th Annual Conference Animal Science of Nigeria.91-93

Ahaotu, E. O., Njoku, P. O., Karsten, K., Yang, N., Ekenyem, B. U., Korie, A. U. and Madubuike, F. N. 2009. Effects of Partial Replacement of Soybean Meal with Cassava Leaf Meal in Broiler Finisher Rations. Anim Prod Adv, 5: 295-299.

Akinfemi, A., Adu, O. A. and Doherty, F. 2009. Assessment of the nutritive value of fungi treated maize cob using in vitro gas production technique. Livestock Research for Rural Development, Vol. 21:11.

AOAC. 2000. Official methods of analysis. Association of official Analytical chemists $\left(17^{\text {th }}\right.$ edition). Arlington.

Atteh, J. O. 2000. The use of enzyme to improve the nutritive value of wheat milling by-product (wheat bran) in poultry feeds. Proceedings of the Seminar on Starting the New Millennium with an Array of Tailor-Made Biochemical Improved for Flour Milling and Baking Industry, May 2000, Lagos, pp: 4-27.

Bounous, I. D., Wyatt, R. D., Gibbs, P. S., Kilburn, J. V. and Quist, C. F. 2000. Haematological and Serum biochemical reference intervals for juvenile wild turkeys. Journal of Wildlife Diseases; 36(2):393-396.

Brown, B. A. 1976. Haematology principle and procedure $\left(2^{\text {nd }}\right.$ ed.) Philadelphia, U. S. A: Lea and Fabigor

Carola, R.., Harley, J. P. and Noback, C. R. 1990. Human Anatomy and Physiology. McGraw-Hill Inc. USA. 925pp.

Coles, E. H. 1986. Veterinary Clinical Pathology of Domestic Animals. 2nd ed. Academic Press, New York, USA.

Dacie, J. V. and Lewis, S. M. 1984. Practical haematology. $6^{\text {th }}$ Edition Churchill living stone. Edinburg.

Daniel, M. C. 1970. Standard methods in serum enzyme activities. Clinical chemistry Vol. 6: 159.

Keele, C. A. and Neil, E. 1971. Samson Wrights Applied Physiology. 12th Edition, ELBS and OUB, 
London.576pp.

Mitruka, B. M. and Rawnsley, H. M. 1977. Clinical biochemical and hematological reference values in normal experimental animals. USA, Masson Publishing Inc., 134-135

Nwokolo, E. N., Akpapunam, M. and Ogunjinmi, T. 1985. Effect of varying levels of dietary fibre on mineral availability in poultry diets. Nigeria Journal of Animal Production. 12: 29-34.

Peter, T., Biamonte, G. T. and Donmas, B. T. 1982. Protein in serum In: Selected method of chemical chemistry G. N. R. Faulkner and S. Meites (Eds) Animal Association of clinical chemistry. Cooper, G. R. and

SAS. 2004. User's Guide: Statistics, version 9.1. SAS institute Inc. Cary, NC, USA.Seattle, Washington. Pp: 156-339.
Tewe, O. O., Job, T. A., Loosli, J. K. and Oyenuga，V. O. 1976 . Composition of two local cassava varieties and the effect of processing on their hydrocyanic content and nutrient utilization by rat. Nigerian Journal of Animal Production 3 (2): 60-66.

Zilva, J. F. and Pannall, P. R. 1984. Clinical Chemistry in Diagnoses and Treatment, 4 Ed. Lloyd-Luke Medical Books Ltd., London, $185 \mathrm{pp}$.

Wintrobe, M. M. 1933. Macroscopic examination of the blood. American Journal of Medical Science, 185: 58-59.

Received: $11^{\text {th }}$ November, 2017

Accepted: $20^{\text {th }}$ February, 2018 